\section{1705 - healthy and high-yielding wheat cultivar for biscuit manufacturing}

\author{
Francisco de Assis Franco ${ }^{1}$, Volmir Sergio Marchioro ${ }^{2 *}$, Adriel \\ Evangelista ${ }^{1}$, Mateus Polo ${ }^{1}$, Tatiane Dalla Nora Montecelli ${ }^{1}$, \\ Leandro Vagno Souza ${ }^{1}$, Ivan Schuster ${ }^{1}$, Fábio Junior Alcântara \\ de Lima ${ }^{1}$, Diego Augusto dos Santos ${ }^{1}$ and Edson Luiz Grave ${ }^{1}$
}

\begin{abstract}
CD 1705 is a cultivar indicated for the wheat-producing regions 1, 2 and 3 of the states of Rio Grande do Sul, Santa Catarina and Paraná. It is appropriate for biscuit manufacturing, has good plant health and high production potential (mean yield of $4308 \mathrm{~kg} \mathrm{ha}^{-1}$ ).
\end{abstract}

Key words: Triticum aestivum L., industrial quality, general gluten strength.

\section{INTRODUCTION}

Wheat is economically highly relevant for the southern region of Brazil, where approximately $90 \%$ of the national production is grown (CONAB 2017). To meet the demands for different uses of this staple cereal for human consumption, wheat cultivars with different characteristics are developed. Cultivars with a high production potential, use-specific quality characteristics (Franco et al. 2011, Marchioro et al. 2015), short plant height, high number of tillers, and large spikes (Franco et al. 2011, Franco et al. 2015) are recommended for cultivation, to meet the different needs of producers.

Commercial wheat is classified as strong (gluten strength $>300 \times 10^{-4}$ joules and stability $>14 \mathrm{~min}$ ), bread (gluten strength $>220 \times 10^{-4}$ joules or stability $>$ $10 \mathrm{~min}$ ), domestic (gluten strength $>160 \times 10^{-4}$ joules or stability $>6 \mathrm{~min}$ ), basic (gluten strength $>100 \times 10^{-4}$ joules or stability $>3 \mathrm{~min}$ ) and other uses.

Currently, the market demand for wheats with specific industrial quality for particular uses has increased, to provide more and better options of wheat cultivars.

\section{BREEDING METHODS}

Cultivar CD 1705 resulted from the cross of lines CD 0536 and CD 0562, performed in Palotina in 2005, and F1 seeds were sown in the same year in a greenhouse, in Cascavel. The plants were harvested at maturity and all spikes bulk-threshed, resulting in the F2 population. The F2 population was grown in a field in Palotina in 2006, using the modified mass method. This procedure consists of the selection of the best plants within a population, threshing the spikes of all selected plants together, and sowing a significant sample of these seeds on a plot with low density of individual plants to grow the next generation. The F3 and F4 populations, respectively, were cultivated by the above method
Crop Breeding and Applied Biotechnology 18: 334-337, 2018 Brazilian Society of Plant Breeding. Printed in Brazil http://dx.doi.org/10.1590/1984$70332018 \mathrm{v} 18 \mathrm{n} 3 \mathrm{c} 50$

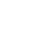


in Palotina in 2007 and Cascavel in 2008. In 2009, the F5 population was grown in Cascavel by the genealogical method. This procedure consists of selecting plants, threshing the spikes of the selected plants together and sowing the seeds of each plant in the next generation in a plot with low density of individual plants. The F6 population was also selected in the field by the genealogical method in Cascavel, in 2010. The F6 population was grown in plots consisting of six 5-m long rows, spaced $0.17 \mathrm{~m}$ apart. selection was performed for short plant height, high number of tillers, large spikes and disease tolerance. At this stage, the traits of several sibling lines had become fixed, and one line (CD 12203) was selected, from which CD 1705 (pedigree CC18707-00P-00T-1T-2T-0T) was derived.

\section{TRAITS AND PERFORMANCE}

Line CD 12203 was included in the HC (Hot/Cold) genotype collection in 2011, and was assessed in 2012, in Preliminary tests in Cascavel/PR, Palotina/PR, Guarapuava/ PR, Não-Me-Toque/RS, and in São Gotardo/MG, where its yields exceeded those of the controls. Prior to sowing, the seeds were treated with Triadimenol + Imidacloprid. The locations of tests for the Value for Cultivation and Use (VCU) of 2013-2015 were distributed at different locations in the wheat-producing regions (Cunha et al. 2006) and different winter growing seasons (Table 1). The experiment was arranged in a randomized block design, with three replications, in plots with six 5-m long rows, spaced $0.17 \mathrm{~m}$ apart. Fertilization and disease, pest and weed control were applied according to the official technical recommendations (Comissão 2013).

The variables measured in the VCU tests were grain yield (obtained from the weight of each plot after moisture correction of the grains), days from emergence to heading, days from emergence to maturity, plant height, lodging, hectoliter weight, 1000-grain weight, pre-harvest sprouting, and tolerance to soil aluminum. The grains of three replications per treatment were mixed, generating composite samples for quality analyses, evaluating the variables: falling number, gluten strength and alveograph tenacity/extensibility ratio; farinograph stability; and flour color. The latter was determined by the $L^{*} a{ }^{*} b *$ system, which is an international standard for color measurements, in which the $L$ (lightness) values vary from 0 (black) to 100 (white) and the $a$ and $b$ values (chromaticity coordinates) range from - $a$ (green) to $+a$ (red) and from -b (blue) to $+b$ (yellow). At strategic locations, the genotypes participating in the VCU tests were grown together without disease control, and the diseases leaf rust, leaf spot, powdery mildew, fusarium head blight, blast and mosaic virus were evaluated, among others.

The plant height of cultivar CD 1705 is short $(77 \mathrm{~cm}$ ), ranging from 65 to $87 \mathrm{~cm}$ (classified according to the morphological descriptors for the species). The cycle is early (58-86 days from emergence to heading; 110-143 days from emergence to maturity). The averages of these characteristics were 69 and 124 days, respectively. CD 1705 has spindle-shaped and pending spikes. It was classified as moderately resistant to lodging and moderately resistant to pre-harvest sprouting. The mean hectoliter weight was $78 \mathrm{~kg} \mathrm{hL}^{-1}$, that is, classified as type 1 wheat (Comissão 2013). The 1000-grain weight is 31

Table 2. Means of general gluten strength (W), farinograph stability time (ST), falling number (FN), tenacity/extensibility ratio (P/L), flour color (COL L, COL a and COL b) per wheat-growing region in samples of tests conducted in the states of Rio Grande do Sul, Santa Catarina and Paraná, from 2013 to 2015

\begin{tabular}{lcccccccc}
\hline Wheat-growing region & Nr. of samples & $\begin{array}{c}\text { W } \\
\left(\times 10^{-4} \mathrm{~J}\right)\end{array}$ & $\begin{array}{c}\mathrm{ST} \\
(\mathrm{min})\end{array}$ & $\begin{array}{c}\mathrm{FN} \\
(\mathrm{min})\end{array}$ & $\mathbf{P} / \mathbf{L}$ & $\begin{array}{c}\text { COL L } \\
(89 \text { to 96) }\end{array}$ & $\begin{array}{c}\text { COL a } \\
(-1.0 \text { to }+1.0)\end{array}$ & $\begin{array}{c}\text { COL } \mathbf{b} \\
(6 \text { to 10) }\end{array}$ \\
\hline 1 & 4 & 115 & 5.2 & 403 & 0.8 & 92.4 & -0.1 & 9.8 \\
2 & 6 & 147 & 5.62 & 380 & 0.7 & 92.5 & -0.04 & 10.0 \\
\hline
\end{tabular}




\section{FA Franco et al.}

grams, i.e., in spite of having small grains, the productivity is high and at sowing, this feature means savings in the quantity of seeds.

In the VCU evaluations at specific locations from 2013 to 2015 without disease control, information was obtained for the classification of the genotype sets tested, including cultivar CD 1705, for their reaction to the main diseases. CD 1705 was classified as moderately resistant to powdery mildew (Blumeria graminis f.sp. tritici), leaf rust (Puccinia triticina), leaf spots (Septoria tritici and Bipolar sorokiniana), and glume blotch (Septoria nodorum) and blast (Pyricularia grisea). For scab (Fusarium graminearum), it was classified as moderately resistant to moderately susceptible.

The mean gluten strength (W) was determined at 135 $\mathrm{x} 10^{-4}$ joules, with a tenacity and extensibility ratio of 0.7 and water absorption of 58\%, classifying CD 1705 in the groups of basic wheat cultivars (Table 2). The industrial quality of wheat cultivar CD 1705 is equal to or higher than that of others already indicated for biscuit manufacturing (Franco et al. 2010, Marchioro et al. 2011, Caierão et al. 2013, Marchioro et al. 2013, Franco et al. 2016)

The mean grain yield of cultivar CD 1705 in the wheat-growing regions 1, 2 and 3, respectively, were 3\%, 2\% and $5 \%$ higher than those of the controls (Table 3 ). The overall mean grain yield was $4308 \mathrm{~kg} \mathrm{ha}^{-1}$, exceeding the controls by $3 \%$. In view of the grain yield performance of CD 1705, the cultivar was indicated for cultivation in the wheat-growing regions listed above, for the states of the southern region of Brazil. The cultivar was registered by the Registro Nacional de Cultivares ( $n^{\circ}$ 35805). Cultivar CD 1705 is suitable for biscuit manufacturing, has good plant health and a high production potential, representing a promising option for farmers of Rio Grande do Sul, Santa Catarina and Paraná.

\section{BASIC SEED PRODUCTION}

The company COODETEC Desenvolvimento, Produção e Comercialização Agrícola Ltda (BR 467, km 98, PO Box 89, 85813-450, Cascavel, Paraná, Brazil), is authorized to license seed companies to produce protected varieties (law no 9456/97), to multiply and sell seed to grain producers. Cultivar CD 1705 was released on the market in 2017, with an availability of five tons of seeds.

\section{REFERENCES}

Caierão $E$, Silva MS, Scheeren PL, Eichelberger L, Nascimento Júnior A, Guarienti EM, Miranda MZ, Costamilan L, Santana FM, Maciel JLN, Pires JL, Lau D, Pereira PR, Cargnin A and Castro RL (2013) BRS 374 - Wheat cultivar. Crop Breeding and Applied Biotechnology 13: $212-214$.

Comissão Brasileira de Pesquisa de Trigo e Triticale (2013) Informações técnicas para trigo e triticale - safra 2013. Instituto Agronômico do Paraná, Londrina, 220p.

CONAB - Companhia Nacional de Abastecimento (2017) Acompanhamento da safra brasileira de grãos 2017/18 Terceiro levantamento. Conab, Brasilia, 130p. Available at <http://www.conab.br>. Accessed on Dec 18, 2017.

Cunha GR, Scheeren PL, Pires JLF, Maluf JRT, Pasinato A, Caierão E, Silva MS, Dotto SR, Campos LAC, Felício JC, Castro RL, Marchioro V, Riede
Table 3. Grain yield means ( $\mathrm{kg} \mathrm{ha}^{-1}$ ) of cultivar CD 1705 and the controls in the tests carried out in the wheat-growing regions, Paraná, from 2013 to 2015

\begin{tabular}{lcccccc}
\hline Wheat-producing region & Cultivar & $\mathbf{2 0 1 3}$ & 2014 & 2015 & Mean & \% \\
\hline \multirow{4}{*}{$\mathbf{1}$} & $C D 1705$ & 6217 & 6036 & 4095 & 5449 & 103 \\
& $C_{1}$ & 5883 & 5911 & 4242 & 5345 & 101 \\
& $C_{2}$ & 5796 & 6027 & 4038 & 5287 & 99 \\
& $C_{M}$ & 5840 & 5969 & 4140 & 5316 & 100 \\
\hline & $C D 1705$ & 5553 & 4804 & 5009 & 5122 & 102 \\
& $C_{1}$ & 5408 & 4762 & 4744 & 4971 & 99 \\
& $C_{2}$ & 5109 & 5194 & 5014 & 5106 & 101 \\
3 & $C_{M}$ & 5259 & 4978 & 4879 & 5038 & 100 \\
\hline & $C D 1705$ & 1270 & 3532 & 2254 & 2352 & 105 \\
& $C_{1}$ & 1274 & 3212 & 2240 & 2242 & 100 \\
& $C_{2}$ & 1086 & 3178 & 2314 & 2193 & 100 \\
& $C_{M}$ & 1180 & 3195 & 2277 & 2217 & 100 \\
\hline
\end{tabular}

$\mathrm{C}_{\mathrm{m}}=$ Control means. The controls $\mathrm{C}$ and $\mathrm{C}$ were, respectively, cultivars BRS Guamirim and Quartzo in 2013, and CD 1440 and TंBIO Sinuelo in 2014 and 2015. 
CD 1705 - healthy and high-yielding wheat cultivar for biscuit manufacturing

Dalla Nora T, Santos DA and Grave EL (2016) CD 1805 - Wheat with flour characteristics for cookie baking. Crop Breeding and Applied Biotechnology 16: 74-76.

Marchioro VS, Franco AF, Dalla Nora T, Oliveira ED, Schuster I, Evangelista A, Rocha R and Polo M (2011) CD 120 - wheat cultivar, standard quality soft, for the Southern Region of Brazil. Crop Breeding and Applied Biotechnology 11: 375-378.
Marchioro VS, Franco AF, Dalla Nora T, Schuster I, Evangelista A, Lima FJA and Polo M (2013) CD 121 - Cultivar with flour characteristics for cookie baking. Crop Breeding and Applied Biotechnology 13: 144-146.

Marchioro VS, Franco AF, Schuster I, Dalla Nora T, Lima FJA, Polo M and Evangelista A (2015) CD 154: Strong gluten wheat with high production potential. Bioscience Journal 31: 1304-1306. 